\title{
Evolution of Science and Technology Policy in Korea
}

\author{
Ji Woong Yoon*
}

\begin{abstract}
This paper provides an overview of the key policy instruments and capacity building policy tools used in each development phase of science and technology in Korea. In the 1960s and '70s, the Korean government built an institutional foundation for the development of science and technology. In the later part of the '60s, the Ministry of Science and Technology and the governmentfunded research institute became key organizations to implementation of policies intended to foster the advance of science and technology in Korea. The Korean government also focused on learning about and absorbing foreign technologies by licensing and by importing capital goods. From 1980 to 1997, the Korean government shifted its policy direction from technology learning to developing by its own scientific and technological capacity in high-technology sectors, which requires an indigenous $R \& D$ capability. It launched large-scale $R \& D$ programs that targeted certain fields to close what was a large gap between advanced countries and Korea. Korea became a fast follower, making a massive investment in certain fields, such as the semiconductor, electronics, steel and chemical industries. In the late 1990s, the Korean government developed a plan to build a national science and technology innovation system. Although the relevant infrastructures had been in place for 40 years and an R\&D capability for innovation was in the works, those were not perceived to be systematically working together, which is crucial for sustainable innovation. The government response to this problem was to design a policy that tried to systemize the whole process of science and technology innovation.
\end{abstract}

Key Words: science and technology policy, R\&D policy, policy instruments, regulatory policy, distributive policy, capacity building

\section{INTRODUCTION}

The rapid economic development of Korea within a half century caught the attention of many other developing countries. No other country with a colonial background has

* Ji Woong Yoon is an associate professor in the Department of Public Administration at Kyung Hee University. E-mail: jiwoongy@khu.ac.kr.

Manuscript received February 10, 2014; out for review March 3, 2014; review completed April 16, 2014; accepted April 19, 2014.

The Korean Journal of Policy Studies, Vol. 29, No. 1 (2014), pp. 147-172.

(C) 2014 by the GSPA, Seoul National University 
achieved a miracle like Korea. Korea's economic development has been called "a compressed growth," owing to how quickly it happened. Once the poorest country on earth, a country with $\$ 87$ per capita income in the '50s, Korea is now the 15th largest economy in terms of GDP and a member of OECD. Remarkably, Korea has built an indigenous R\&D capability that enabled the export of cutting-edge products, such as semi-conductors, LCD panels, and smart phones.

Among many factors that have contributed to the economic development of Korea, the policies associated with science and technology (S\&T) are regarded as crucial. How did Korea become competitive in S\&T, starting with almost no tangible or intangible S\&T basis? What was the policy direction, and how was it planned and organized? How did the government implement the policies?

To provide answers to these questions, this paper examines the major policy instruments used to achieve policy objectives and to build a S\&T R\&D capacity and provides an overview of how S\&T R\&D has performed in the wake of policy implementation. The key policy instruments examined in this paper are distributive and regulatory ones based on Lowi's policy instrument classification. Regulatory policy instruments include legal mandates that oblige the government to establish organizations and secure resources to implement S\&T policies. Distributive policy instruments include direct subsidies and financial support for launching and running scientific research and technology development programs (Lowi, 1968).

Moreover, R\&D capability cannot be obtained automatically. It requires human beings who have received a solid education and training and who can conduct research, although it can also be obtained through technology import and reverse engineering. In addition, an incentive system or an evaluation system that can manage the performance of S\&T development programs is crucial. Without a system to monitor and evaluate $R \& D$ programs, it is very difficult to effectively plan future $R \& D$.

This paper provides a detailed account of the S\&T policy instruments used and policies to build capacity for R\&D elaborated in successive presidential administrations in Korea. The development stages of S\&T policy can be roughly divided into three stages. In the first stage, the government, under President Park in the 1960s and '70s, set up an institutional foundation for the development of S\&T. S\&T policy was a crucial part of the five-year economic development plan, and the relevant laws and institutions were created, although almost no infrastructure existed and personnel were lacking. In the later part of the '60s, the Ministry of Science and Technology (MST) and the government-funded research institute were established to implement policies to foster the advance of S\&T. In addition, the Korean government focused on learning about and absorbing foreign technologies by licensing and importing capital goods. Foreign direct investment (FDI) was not a preferred method of financing economic 
growth, as the public perceived FDI as being dependent on foreign countries' technology and systems.

In the second stage, from 1980 to 1997 under the administrations of Chun Doohwan, Roh Tae-woo, and Kim Young-sam administrations, the Korean government shifted its policy direction from technology learning to developing by its own scientific and technological capacity in high-technology sectors, which required an indigenous R\&D capability. In this stage, the government launched large-scale R\&D programs that targeted certain fields. The government was able to target promising S\&T areas by benchmarking the policies of the advanced countries. Korea subsequently made a massive investment in order to take advantage of the economies of scale in certain fields, such as the semiconductor, electronics, steel, and chemical industries.

In the third stage Korea tried to synthesize and enhance a systematic S\&T innovation system. In the late '90s, Korea experienced a financial crisis that changed the social and economic structure of the country. There are many anecdotal reasons proffered as to what caused the crisis. One is that Korea's economic development was too fast and that it did not have a sound and solid foundation to sustain economic growth. Although the relevant infrastructures had been in place for 40 years and a R\&D capability for innovation was emerging, those were not perceived to be systematically working together, which is crucial for sustainable innovation. The government responded to this problem by designing a policy that tried to synthesize and systemize the whole process of S\&T innovation.

\section{POLICY INSTRUMENTS FOR THE ADVANCE OF S\&T}

\section{Regulatory Policy Instruments for Building S\&T Institutions}

S\&T technology policy was introduced with the first five-year economic development plan in 1962, right after the military coup in 1961 by Park Chung-hee, who later became the president of the third republic of Korea. There is a famous story about how a division of science and technology came to be established within the Korean government.

In 1962 at a briefing Chairman Park Chung-hee asked the general manager of new plant that was being constructed as part of the first 5-year plan whether he had the level of technological capability and human capital he needed for the construction. The question was unexpected and the general manager did not have an answer that had been prepared by government officials. The general manager avoided the embarrassing situation by saying that he would prepare another briefing within two weeks (Chung, 1982). In order to address the questions raised the chairman , the Science and Technology 
Division was established within the Economic Planning Bureau (EPB), the new officers in that division working fully for two weeks to come up with the answers to the chairman's questions. This was how S\&T policy was born in Korea (Oh, 2006).

Understanding that S\&T were indispensable for economic development, Park endeavored to lay the institutional foundation for it, strongly and consistently supporting investment in the physical and institutional infrastructure for S\&T development throughout his presidency (Kim, 2008). The first five-year technology promotion plan (1962-1966), for example, was the first comprehensive plan that aimed to generally promote S\&T. The action items included in the plan were carried out together with the five-year economic development plan (MST, 2008), S\&T policy effectively helping implementing the economic development plan.

As the Korean economy expanded, the government also grew rapidly. S\&T policyrelevant institutions, such as laws and organizations, had to be expanded to meet the policy demand. Hence, in 1967, the Science and Technology Promotion Act was enacted. This law stipulated the roles and scope of the government in S\&T development and provided a basis for establishing a "comprehensive science and technology promotion plan" and implementing S\&T policies and projects (MST, 2008).

In 1967, the Park administration established the MST. It was a spin-off from the Science and Technology Division within the EPB. The EPB and the president's senior secretary for economic policy in the Blue House strongly influenced the S\&T policy agenda, although their role was to concentrate on relatively short-term economic development policy while the role of MST was to plan and advise the president on a long-term S\&T development plans. However, their influence was offset in the late '60s when President Park appointed Dr. Choi Hyung-syup, whom he trusted, as a minister of the MST. Choi remained in that position for almost eight years, the longest term for any minister of the MST, which allowed for the articulation of a consistent and sustainable policy for S\&T development. Choi created an environment where scientist and technicians could enthusiastically work without any concerns and also established Daedeok Science Town, which became a successful high-technology cluster in Korea 30 years later.

\section{Restructuring S\&T Policy Institutions}

To build an efficient S\&T policy system, the Chun doo-hwan administration restructured the government organizations associated with S\&T policy and merged the 16 government-funded research institutes (GRIs) affiliated with five different ministries that had been established in the late 70s, reducing their number to 9 and putting them solely under the control of the MST. Moreover, President Chun eliminated the second 
senior secretary to the president for economic policy position, which had overseen S\&T policy (Cho \& Sung, 2005). The organizational restructuring was intended to build an S\&T administrative system that could nurture and develop national R\&D projects efficiently in connection with the integrated operation of GRIs (Min, 2007).

As a result, in the Chun doo-hwan administration, the influence of the senior secretary for economic policy on the S\&T policy was powerful. The senior secretary played a key role in the decision-making process of S\&T policy, overseeing the affairs related to S\&T, which was distributed among the branches of the government, resolving conflicts among the branches and coordinating different views, and making proposals to the president (MST, 2008).

President Chun lacked legitimacy as president since he had secured that position through a military coup, and so he created a slogan emphasizing Korea's science- and technology-driven economic development as a way of compensating for his lack of legitimacy. He appointed scientists whom he trusted and a man who had gone to the Korea military academy with him as the minister of the MST, which meant the ministry had political support and power throughout the period.

The Chun doo-hwan administration recognized the need for a national advisory committee in planning and implementing S\&T policy given how rapidly the field had grown and how specialized it had become and so established the Science and Technology Promotion Review Council and also created policy coordinator and research administrator positions for specific technology fields (Cho \& Sung, 2005). The Chun doo-hwan administration used this council as a tool to secure a consensus for the S\&T policy agenda.

The Roh Tae-woo administration maintained the S\&T policy structure of the Chun doo-hwan administration. As this administration was more focused on setting up a democratic political system in Korea, it did not design or implement many new S\&T policies. However, in 1987, it did establish a presidential advisory council on S\&T, the only S\&T organization based on the constitution, which remained a temporary organization until 1991. Eleven advisors were personally appointed by the president to help him make decisions and implement policies. The advisory council played an important role at the end of the sixth republic, as most of the policies recommended by it after it had held 20 meetings were confirmed as the government's S\&T policy with little or no modifications (MST, 2008).

The enactment of a law by the Roh administration to facilitate basic science, which resulted in the establishment of the Korea Basic Science Institute in 1988, set the foundation for the advance of basic research in Korea. Simultaneously, the Korean Research Foundation launched a program for funding research centers in the universities. But the amount of this funding was less than that for the applied research and the technology 
development programs, because the government and private sectors were more focused on short-term outcomes, and university research capacity was not geared toward short-term projects.

The Kim Young-sam administration proactively addressed the policy agenda for S\&T. First, it established an S\&T minister council that consisted of the ministers associated with S\&T, chaired by the vice prime minister of economy. This council was the key decision-making institution of S\&T policy, as the vice prime minister was in charge of budgeting, although the president's senior secretary for economic policy still had influence on S\&T policy to an extent. In 1994, the first year of the Kim administration, the S\&T R\&D budget was increased by $32.7 \%$ (around $\$ 2$ billion USD), double the average annual increase rate of $16 \%$ that prevailed between 1981 and 1993.

In addition, the Kim administration enhanced R\&D programs that had been launched in the previous administrations by adding its own policy agenda, "informatization," and by establishing the Ministry of Information and Communication (MIC) in 1994. The administration targeted information and communication technology (ICT) as a growth field because it is a sector that has a broad impact on the economy. The Ministry of Postal Service was chosen as a base organization for the MIC, and other government organizations associated with economic planning, industry policy, and communication technologies were merged into this ministry. Government officials from the EPB were one dominant group in the MIC, as the EPB was merged with the MIC at the same time the MIC was created. Along with this organizational change, a special budget for fostering informatization was devised to implement the policy agenda. These changes allowed the Korean government to plan an integrated policy framework for ICT development. The MIC was able to implement ICT R\&D policy with the help a framework act for promoting informationalization that was enacted in 1995.

\section{Funding Large-Scale National R\&D Programs}

While S\&T policy in the '60s and '70s aimed to learn imported technologies and support economic development, in the ' 80 s and ' 90 , it shifted toward developing indigenous $\mathrm{R} \& \mathrm{D}$ capability, and encouraging national competitiveness. To this end, the government designed a large-scale national $R \& D$ program targeting promising fields.

The national R\&D program was first initiated by the MST in 1982. The program has made significant contributions to economic growth as well as the improvement of the quality of life. In the twenty-first century, national R\&D efforts are being geared toward meeting the challenges connected with the move to a knowledge-based economy 
with a view to placing the nation among the ranks of the advanced economies. In order to accomplish this goal, the government emphasizes efficient use of S\&T resources based on the principle of "selection and concentration."

The government developed technologies for mid-to long term S\&T projects and launched specific R\&D projects to lead technology development in the private sector. Even though there was a high risk in the early days associated with implementing specific R\&D projects, the government covered all expenses for the projects it promoted for the sake of the public interest. The government funded GRIs to operate and manage many large-scale R\&D projects, such as national R\&D projects, industrial genetic technology development projects, and advanced national R\&D projects.

National R\&D projects primarily targeted new technology areas (to Korea) with a high risk of failure or with high economic externalities, which justified public support. The MST identified several areas: localization of machinery parts and components, new materials development, semiconductor design, superminicomputer development, energy conservation technology, localization of nuclear energy fuel, new chemical development, biotechnology development, and basic research in universities (MST, 2008).

Industrial genetic technology development projects focused mainly on developing technologies that could solve problems in technology areas with a high economic impact (MST, 2008). According to Linsu Kim, most of them were related to import substitution of Japanese components in the electronics and machinery industries. In 1989, for instance, 174 technologies were identified, 146 of which were designated as projects to be funded (Kim, 1997). Advanced national $R \& D$ project, also known as the G-7 project, are multi-ministry R\&D programs aimed at lifting Korea's technological capability to the level of G-7 countries by 2020. At the beginning of the 1990s, the worldwide paradigm change to digitalization and informatization compelled the government to revise its S\&T policies (Kim, 1997).

The G-7 project was pursued into two tracks. One is product technology development and the other is fundamental technology development. The product technology development projects include new drugs and chemicals, broadband integrated services digital network, next-generation vehicle technology, and high-definition television. The fundamental technology development projects contain ultra-large-scale integrated circuits, advanced manufacturing systems, new materials for the information, electronics, and energy industries, environmental technology, new functional biomaterials, alternative energy technology, and next-generation nuclear reactor (Kim, 1997). The $\$ 1.3$ billion invested during the first three years paid the salaries of more than 13,000 researchers and resulted in 2,542 patent applications, almost 2,000 academic articles, and 3 cases of technology export valued at $\$ 6$ million USD. Notable outcomes include liver disease 
treatment medication, high-definition television, and the completion of a $256 \mathrm{M}$ dynamic random-access memory chip (MST, 2008).

The fields that were targeted by the Korean government were the fields that were being funded in the advanced countries, as it aimed to quickly catch up to the advanced countries. Recently designed and launched large-scale R\&D national programs include a global frontier R\&D program, a creative research initiative, a national research laboratory, a biotechnology development program, and a space and aeronautics program.

\section{Funding Basic S\&T Research}

Although Korea underwent rapid economic development, its capacity for creating new breakthrough technology was still limited in the 1980s. The government concluded that it was due to a lack of fundamental S\&T research capability compared to other advanced countries. Such a capability, critics argued, comes from the strength of university research rather than from GRIs, which are oriented toward the government's policy direction. As the GRIs had to conduct research on topics that the government ministries were interested in, it was difficult to carry out autonomous and fundamental research that did not match the needs of various ministries.

However, until recently, universities in Korea were not fully equipped with advanced research facilities and lacked appropriate research funds. Moreover, even until the '90s, the universities in Korea were teaching oriented rather than research oriented, although more than $70 \%$ of those who had earned doctoral degrees were working at universities (Yim, 2004). Although the law for basic science promotion was enacted in 1989 and the funding for basic science and research had begun to increase in the early '90s, it took almost ten years for basic R\&D activities to satisfy expectations. For example, even as late as 2001 , only $10.4 \%$ of national R\&D investments were allocated to universities, while the GRIs and private industries received $13.4 \%$ and $76.2 \%$, respectively (MST, 2007).

The Kim Dae-jung administration announced a plan to increase the funding for basic S\&T research at the universities up to $25 \%$ of the government R\&D budgets by 2006, and to make good use of this funding, a policy was designed to enhance basic S\&T research competence and boost their R\&D capability. According to Deo Soom Yim,

"in order to promote university research, the government designates university research groups with distinctive research capabilities as centers of excellence. The COE includes [sic] Science Research Centers (SRCs), Engineering Research Centers (ERCs) and Regional Research Centers (RRCs). The SRCs and ERCs 
focus on cooperative research between regional universities and industries. The SRCs and ERCs are selected on the basis of their research capability and performance. In the selection of the RRCs, the capabilities to contribute to the regional economy and community are important factors. Once the centers are selected, they receive government funding for nine years provided that they survive the interim evaluation which is conducted every three years. So far 2006, forty-three SRCs, fifty-seven ERCs, and fifty-four RRCs have been selected and funded" (Yim, 2004).

Another policy was to foster top-quality scientists and engineers by transforming teaching-oriented universities into research-oriented universities. To stimulate this change, the government provided financial incentives to those universities with excellent research output. Many of the major universities in Korea have responded to this policy by embarking on reform programs anticipated to bring about drastic changes in university education, changes that will reinforce a culture of research. For example, the Brain Korea 21 (BK 21) project launched in 1999 and completed in 2012, was a large-scale project that aims to cultivate the creative and high-quality human resources necessary for basic S\&T R\&D. To accomplish this aim, the government decided to invest $W 1.4$ trillion (about $\$ 1.2$ billion USD) in universities over seven years. Three-quarters of the budget was invested in supporting graduate schools in certain fields in the natural and applied sciences, humanities, and social sciences to turn them into leading world-class universities. The rest were made into regional vocational universities. The students in the selected graduate schools were the direct beneficiaries of the project, rather than professors, a large part of the budget having been used to provide a supportive educational environment for them in the form of stipends, financial support for overseas study, and research infrastructure. The overall objectives, plans to support universities, expected outcomes, and funding sources of the BK21 project are described briefly below (Ministry of Education and Human Resources Department, 2001).

\section{Advancing the National S\&T Innovation System}

In January 1999, the Kim administration established the National Science and Technology Committee (NSTC) as the highest decision-making and coordinating body of S\&T policy. The president appointed himself as the chairman so as to ensure full political support for the coordination of S\&T policy. Because there many government entities involved in planning and conducting $R \& D$ programs and because the size of the national $R \& D$ funds had rapidly expanded, there was a need for cross-governmental policy coordination to keep the R\&D programs cohesive with the national policy agenda.

In 2001, the NSTC announced a long-term plan for S\&T development and created 
a framework act to implement this plan. In addition, based on the 1988 S\&T law, a basic S\&T plan was conceived, the first comprehensive government-wide plan for S\&T development. In turn, based on this plan, technology roadmaps for 99 selected technology fields were drawn up (Chung, 2010).

However, the status of NSTC was not stable and the scope of coordination was limited. Although the chair was the president, the operating organization was the MST, which is not when it comes to S\&T policy issues, and the budget was controlled by the Ministry of Planning and Finance, so the MST lacked the legal authority to allocate budgets based on the evaluation of R\&D programs conducted in other ministries. As the level of S\&T R\&D advanced, more participants and multiple ministries became involved in designing and implementing the programs. As a result, coordinating S\&T policy among the ministries became more difficult than ever.

To address this problem, the Roh administration presented a plan for the "realization of a science- and technology-oriented society," indicating that S\&T had become the main national policy agenda. Establishing a Korean-style national innovation system (NIS) to encourage sustainable economic development and industrial competitiveness was one of the administration's prime objectives (Park, 2006).

NISs have been broadly defined as the structural and functional profiles of a nation that determine its innovative capability and economic performance (Freeman, 1987). In a rapidly changing technological progress, and competitive global markets, a country's NIS is expected to integrate the roles of all the key players, such as government, education, business, finance, and civil society, in a process of nationwide innovative activities (Porter and Stern, 2002). These subsystems comprehensively highlight major policy, structural and institutional requisites that a country should establish in developing and/or restructuring its national innovation systems.

In this regards, the Roh administration's efforts to establish a Korean version of a NIS considerably contributed to the development of systematic approach to S\&T policy. The government accumulated the relevant data and put a system in place to evaluate national S\&T R\&D programs. Using this monitoring and evaluation system, the government adjusted the budgets for ministries and offices with S\&T components accordingly.

In 2004, President Roh promoted the minister of the MST to vice prime minister, whose job included coordinating and supervising R\&D projects managed by the Ministry of Commerce, Industry and Energy and the MIC that were critical to national R\&D project implementation (Kim \& Yoon, 2008). Moreover, President Roh created a senior secretary for S\&T policy position, showing his political support for S\&T development. In addition, the MST's responsibilities were expanded to include planning and evaluating $R \& D$ policies and programs and further coordinating the national R\&D budget allocation. The MST assigned R\&D programs to various ministries in line with their 
objectives, except for big science and composite $R \& D$, basic $R \& D$, and advanced $R \& D$ programs.

The Roh administration also established an S\&T innovation headquarters to support the vice prime minister in implementing the pangovernmental integration, planning, coordination, and evaluation duties of the MST in line with national development strategy (Kim \& Yoon, 2008). The office was composed of the public servants of the MST, public servants of the related ministries and offices, and experts in the private sector in the ratio of 4:4:2 (MST, 2008). During the Roh administration, the NSTC was also able to operate as a nationwide S\&T policy coordinator with the support of the innovation headquarters.

\section{Responding to Global S\&T Policy Agendas}

Korea's GDP in 2011 was ranked 15th in the World (International Monetary Fund, 2012). It also earned a very high score of 0.897 in the UN's 2012 Human Development Index (HDI), which is used as the common measure of the quality of life in the world (United Nations, 2012). As a consequence of its accelerated economic growth, however, Korea's emission of CO2 almost doubled between 1990 and 2005 (Jones \& Yoo, 2010), although in 2008 South Korea was the 10th largest energy consumer in the world, consuming approximately 227 million ton of oil equivalent (Mtoe) of primary energy annually (U.S. Energy Information Administration, 2011).

Hence, in 2009, the Lee administration introduced a green growth policy as part of the nationwide S\&T policy agenda with the aim of making Korea a global leader among low carbon societies. Its goal is to become the seventh green world power by 2020 and the fifth by 2050 (Green Technology Center, 2012). To achieve these goals, the government issued a framework act on low carbon green growth in 2009. All new S\&T programs were designed to meet the objectives of the new policy, and all existing national $S \& T$ programs were restructured to bring them into line with the new regulations.

Since Korea imports approximately $96 \%$ of its primary energy sources, the first objective has been to improve energy independence by developing alternative energy technologies, which may also help the country achieve its national goal of reducing greenhouse gas to 244 million tons by 2020 (a 30\% decrease compared to a businessas-usual projection). The second objective was to develop green technologies and promote a green structure for industry (Lee, 2011). To this end, the Korean government prioritized the following ten strategic-energy technologies: high-efficiency photovoltaic (PV) cells, fuel cells, advanced nuclear power, green cars, smart grid, advanced carbon capture and storage, water treatment, rechargeable batteries, light emitting diodes, and 
green IT.

To facilitate the fulfillment of the green growth strategy, the Lee administration introduced a five-year action plan (2010-2015). According to the plan, Korea will invest approximately $2 \%$ of its GDP (around $\$ 23$ billion USD) annually in green growth projects, which is double the amount recommended by the UN. It also plans to encourage private businesses to invest in the renewable energy field. Private investments are vitally important for the economics of any country and are considered to be of the most important factors for successful growth in the postcrisis world (Spence \& Leipziger, 2010). Private investments in green businesses have contributed to reducing greenhouse gas emissions. An environmental impact assessment of greenhouse gases that was carried out in Korea states that from 2010 to 2011 greenhouse gases were reduced by approximately 11.47 million tons due to the development of 53 new businesses in the green technology field (U.S. Energy Information Administration, 2011).

\section{CAPACITY BUILDING FOR S\&T DEVELOPMENT}

\section{Funding for Education and for Absorbing External Technology}

As Korea lacked scientific knowledge and technology in the 1960s, the Park administration chose to import the foreign technologies needed to encourage economic development. This strategy was based on the idea that even though these technologies were already being used by advanced countries, if Korea could absorb them quickly and use them to develop exportable products, they would form the basis for a strong economy (Cho \& Sung, 2005).

One way of assimilating and learning foreign technologies is by purchasing them through technology licensing. However, Korea in the 1960s could not license enough technology from the advanced countries at an affordable price; the government sought to control the royalty rate of foreign-technology licensing, but that proved unattractive to firms in advanced countries (Kim, 1997). As an alternative to licensing, the Korean government turned to importing capital goods and turnkey plants, which it financed through long-term foreign loans (see table 1). The government not only invested in specific industries but also in entrepreneurs, who were hired to oversee the new projects, and some of those entrepreneurs later became the owners of so-called chaebols (Chung, 2010).

Korean firms benefited the most from importing capital goods and turnkey plants, because it offered opportunities to work with foreign buyers who provided information about product design and materials as well as about quality control in such sectors as 
Table 1. Technology Import of Korea

(unit: million US\$)

\begin{tabular}{l|c|r|r|r|r}
\hline \multicolumn{1}{c|}{ Source } & \multicolumn{1}{c|}{$1962-1966$} & $1967-1971$ & $1972-1976$ & $1977-1981$ & $1982-1986$ \\
\hline Foreign Direct Investment & 45.4 & 218.6 & 879.4 & 720.6 & $1,767.7$ \\
\hline Foreign Licensing & 0.8 & 16.3 & 96.6 & 451.4 & $1,184.9$ \\
\hline Capital Goods Imports & 316.0 & $2,541.0$ & $8,841.0$ & $27,978.0$ & $50,978.0$ \\
\hline
\end{tabular}

Source: Korean Industrial Technology Association 1994; Korean Society for Advancement of Machinery Industry

the garment and electronic industries (Hobday, 1995). For other light industries, such as shoes, clothing, textiles, and some intermediate goods for import substitution as well as export, the major sources of technological learning were original equipment manufacturing production arrangements (Chung, 2010).

FDI, by contrast, was not popular in the early stages of Korea's development of its S\&T policy. The Park administration discouraged FDI by restricting ownership and repatriation of profits and imposing requirements on technology transfer and exports. Such a restrictive policy was pursued because it was thought that FDI would make Korea technologically dependent on advanced countries (Koo, 1986; Vernon, 1977). For this reason, FDI played a less important role in Korea's acquisition of capital and technology than it did in other developing countries in the early stages of economic development. In the 1970s, Korea further extended its dependence on foreign capital goods and turnkey plants, as it shifted its economic sights toward more capital- and technology-intensive industries. The Korean government implemented massive investment projects to build up the heavy machinery and chemical industries.

Acquiring technology by importing was possible because of the obligatory training program required by the Korean government (Chung \& Branscomb, 1996). The reverse engineering that educated and skilled workers took part in was also crucial (STEPI, 2007). Reverse engineering is a less costly way to acquire knowledge, as it is less mediated by the market, although it does require high level of learning capability and skilled human capital. Korea was able to acquire technologies through this channel as a result of its rich pool of well-educated and motivated citizenry (Kim, 1997).

Korean's education system has to two tracks related to S\&T: one is a higher education track that provides academic and scientific training and the other is skill-based, secondary education track that provides vocational training. The Korean Advanced Institute of Science and Technology (KAIST) was established in 1971. It aimed to become a research-oriented university, offering both master's and $\mathrm{PhD}$ programs since 1975. KAIST was able attract the nation's top-tier students due to the abundant funding from the government since its founding (Yim, 2004). KAIST has attracted highly 
qualified entrants by offering incentives such as full fellowships covering tuition, room, and board and exemption from military obligation. It has produced almost half of trained PhDs in science and engineering in Korea until the mid-90s (Kim, 1997). The government also sponsored students from advanced countries, on the condition that they would work in Korea after graduating. Thus far, KAIST has graduated around 30,000 graduates, over 5,000 of whom have received PhD degrees (Ministry of Education, Science, and Technology, 2013).

During the 1960s and '70s, meanwhile, enrollment in vocational high schools increased, matching the pace of economic growth. The Korean government emphasized vocational education over academic education at the secondary level and encouraged trainees to attend international competitions where they could learn new skills (Moon and Kim, 2001). To mitigate the conventional prejudice against vocational training and attract smart students, the government provided scholarships and attractive employment opportunities (Ministry of Education and Human Resources Department, 2001).

The number of skilled workers increased dramatically, from 0.3 to around 5.0 per population in around 20 years, as a result of the government's efforts. The recruitment of S\&T researchers from abroad to support industrial development in connection with heavy chemical industry development has also contributed to increasing the pool of researchers (Cho \& Sung, 2005).

Korea has one of the highest higher-education enrollment in the world, due to the influence of the Confucian tradition. Higher-education enrollment increased from around $20 \%$ in 1980 to $81.3 \%$ in 2000 , while it was around $63.3 \%$ in the US and 49.1\% in Japan in 2000 (STEPI, 2007). However, as already noted, until the late '90s, a lot of universities in Korea were oriented toward teaching rather than research, and their research facilities were not sophisticated enough to carry out complex research projects.

\section{Establishing Government-Funded Research Institutes for Self-Reliant S\&T R\&D}

Using S\&T policy to support export-driven economic development, the government recognized the importance of efficient learning and diffusion of imitated foreign technologies. Hence, it came up with the idea that GRIs could play a role not just in developing but also diffusing imported technologies to the private sector, which lacked the resources to do this itself at that time.

The Korea Institute of Science and Technology (KIST), the first GRI in Korea, was established in 1966, financed by official development assistance funding from the United States. As the first GRI, KIST spent a large proportion of the nation's total 
R\&D expenditure in its early years. KIST engaged in a broad spectrum of activities in applied research, ranging from project feasibility studies to $R \& D$ for new products and processes (Kim, 1997). Focusing on industrial technology studies to support the goal of industrial development at that time, KIST took the lead in S\&T, inviting overseas scientists to become key researchers (MST, 2008). It is widely known that the salary of the newly recruited scientists from abroad was several times higher than that of high-level government officials at that time, although the exact amount has not been disclosed (Oh, 2006).

Later in the 70s, in the wake of the changing policy environment such as the Nixon doctrine and establishment of diplomatic relations between the United States and China, the Park administration recognized the importance of a self-reliant R\&D capability as a mean of protecting the nation from physical as well as economic threats. To keep pace with increasing demand of R\&D capability and to support newly targeted heavy industries, the government established 15 more GRIs as spin-offs from KIST in the late '70s, including the Korea Institute of Machinery and Metals, the Electronics and Telecommunications Research Institute, the Korea Research Institute of Chemical Technology, the Korea Research Institute of Standards and Science, the Korea Institute for Energy Research, and the Korea Ocean R\&D Institute. Each institute was designed to develop in-depth capabilities in specific areas and to support the needs of associated ministries. In addition, the Agency for Defense Development was established in 1970 to support the development of a self-reliant defense industry. These institutes worked with private industries to build a technological foundation for industrial development.

The Park administration also created two science parks, relocating GRIs in order to create high-tech clusters. One was Seoul Science Park, which was established in 1966 by merging three R\&D institutes and three economic research institutes. However, the park didn't successfully form the cluster, as it did not attract the attention of private research institutes or start-ups. The other cluster, Daedeok Science Town, was formed in 1973 by with relocating 14 GRIs and 3 tertiary educational institutions (Oh, 2002). President Park's initial plan was to create a science city outside the capital region that would enhance research efficiency through a systematic and comprehensive R\&D investment and the application of diverse approaches(Oh \& Masser, 1995). In order to achieve these goals, the initial stages of Daedeok's foundation centered on public sector research institutes and nationally funded universities. Today there are 30 governmentfunded institutions, 5 universities, over 400 corporate R\&D centers, and more than 1,200 high-tech companies located in this area, which is regarded as one of the most highly favored areas in which to live and work in Korea (Oh \& Yeom, 2012). 


\section{Project-Based System for Managing S\&T Program Performances}

In the late 1980s, the increase in R\&D activities in industrial firms and universities led many scholars and policy makers to point out the relative inefficiency of GRIs, raising questions as to their effectiveness in industrial technology development. For example, the government made an R\&D investment of \$207 million USD from 1982 to 1990 on 2,400 projects that were mainly proposed and carried out by GRIs, but while $30.9 \%$ of the government-funded projects were successfully commercialized, only $4.1 \%$ of them went to market successfully (Kim, Lee, and Yim, 1999). The major criticisms of the GRIs at that time were duplication of research, poor R\&D project management, and low $\mathrm{R} \& \mathrm{D}$ productivity. These problems were mainly attributed to the lack of consensus among the related government authorities and top managers of GRIs on their institutional mission, excessive monitoring and controlling by the government, and the government's unstable budgetary support.

As the first step in dealing with these problems, in 1996, the government changed its R\&D funding system from a lump-sum to a project-based system. Before the introduction of a project-based system, the Korean government fully funded GRIs manpower costs for whatever projects they undertook. However, under the project-based system, the government only supported $30-50 \%$ of manpower costs, and so GRIs had to begin competing with universities and industries for R\&D projects to ensure its manpower costs would be covered (Kim et al., 1999). The project-based system thus contributed to introducing a competitive R\&D funding system in Korea.

There has been some criticism of the project-based system. First, to secure their manpower costs, GRI researchers have been forced to shift their research focus from their mission-oriented projects to projects that satisfy the interests of various ministries (Yim, 2004). Second, since the research budget of GRIS is limited and the number of researchers it can employ is controlled by the government, the project-based system has encouraged GRIs to make more use of cheap temporary researchers. As of 2012, irregular employment, which includes temporarily hired students (Ministry of Science, ICT, and Future Planning, 2013), accounts for about $46 \%$ of the total number of researchers employed by GRIs.

\section{Establishing a National R\&D Performance Management and Evaluation System}

In order to improve the efficiency and effectiveness of national R\&D programs, in 2005, the government enacted a law to regulate the process of R\&D performance assessment and management and the organizations in charge of it. 
The performance evaluation system covers the whole life cycle of the R\&D program. The prefeasibility study for R\&D programs was introduced as a pilot program in 2007 and was officially launched in 2008. The programs that have to undergo a prefeasibility study are new large-scale $R \& D$ programs whose budgets are estimated to be more than $\$ 50$ million USD in total or \$5 million USD annually. The system was designed to calculate technical and policy feasibility, cost-effectiveness, and spread effect in advance and compare those results with various alternatives to determine if the project could successfully implemented (KISTEP, 2009).

In addition, all GRIs are required to submit a self-evaluation performance report, which has two parts. The first is an evaluation of managerial factors, such as finances, organizational changes, and the performances of each division. The second is an evaluation of patent performance, publications, level of royalty fees, and so forth. The first report has to be submitted every year, while the second has to be submitted every three years (MST, 2007). The Korean government also conducts a special evaluation of specific R\&D projects associated with certain R\&D policy. These reports evaluate the extent of the redundancy among R\&D programs with the same goal as well as how effective and efficient the R\&D programs are in achieving their goals.

The national S\&T R\&D evaluation system, a crucial component of S\&T policy given that the funding for national $S \& T$ R\&D has increased significantly in recent years (10\% from 2002 to 2011), was fully implemented by 2008. However, there was a conflict over the management of the evaluation system between the Ministry of Strategy and Finance and the MST. Since the S\&T policy was introduced as a part of the five-year economic development plan, the influence of the Ministry of Strategy of Finance on the S\&T policy was quite strong. However, as S\&T advanced and became more specialized, field expertise became important, and the MST wanted S\&T expertise to be reflected in the S\&T policy planning and budgeting, while the Ministry of Strategy and Finance wanted to keep the national S\&T R\&D budget under its control.

The organizational restructuring of each political regime has complicated this conflict between the two ministries. In 2003 the Roh administration gave authority to the MST, as the minister of the MST was a vice prime minister whose role was to coordinate, budget, plan, and evaluate S\&T R\&D programs. However, in 2008, the Lee administration split the MST into the Ministry of Knowledge Economy and the Ministry of Education, Science, and Technology. As a result, the role of budgeting and evaluating the national S\&T R\&D programs was assigned to the Ministry of Strategy and Finance, although it was not clear which ministry was supposed to coordinate S\&T policy. In 2013, the Park Geun-hae administration created the Ministry of Science and Technology, ICT, and Future Planning, and gave it the role of allocating the S\&T R\&D budget and managing the S\&T R\&D performance and evaluation. 


\section{OVERVIEW OF S\&T R\&D PERFORMANCE}

R\&D expenditure as a percentage of GDP has increased over 400\% since 1980, while the number of researchers increased 600\% from 1980 to 2011. The number of patent applications has increased almost 20 times since 1980, and the number of publications included in the Social Citation Indexes (SCI) almost tripled between 2001 and 2011. In short, Korea has performed extraordinary well over the last 30 years.

A series of policy instruments fostered Korea's performance in different periods. For example, right after the establishment of Daedeok Science Park, R\&D expenditure as a percent of GDP began increasing. Moreover, there was a sharp rise in the R\&D expenditure as a percent of GDP and the number of researchers per 1,000 population when the law of fostering technology development was enacted and when the largescale R\&D programs were launched. This trend in the number of researchers became even sharper when the high-technology development programs were launched. What is also interesting is the increase in the number of patent applications right after the enactment of the law of facilitating technology transfer and commercialization. The following sections provide a more in-depth explanation of the major R\&D outcomes of S\&T policy in Korea.

Figure 1. Major S\&T Policy Instruments Used in Korea

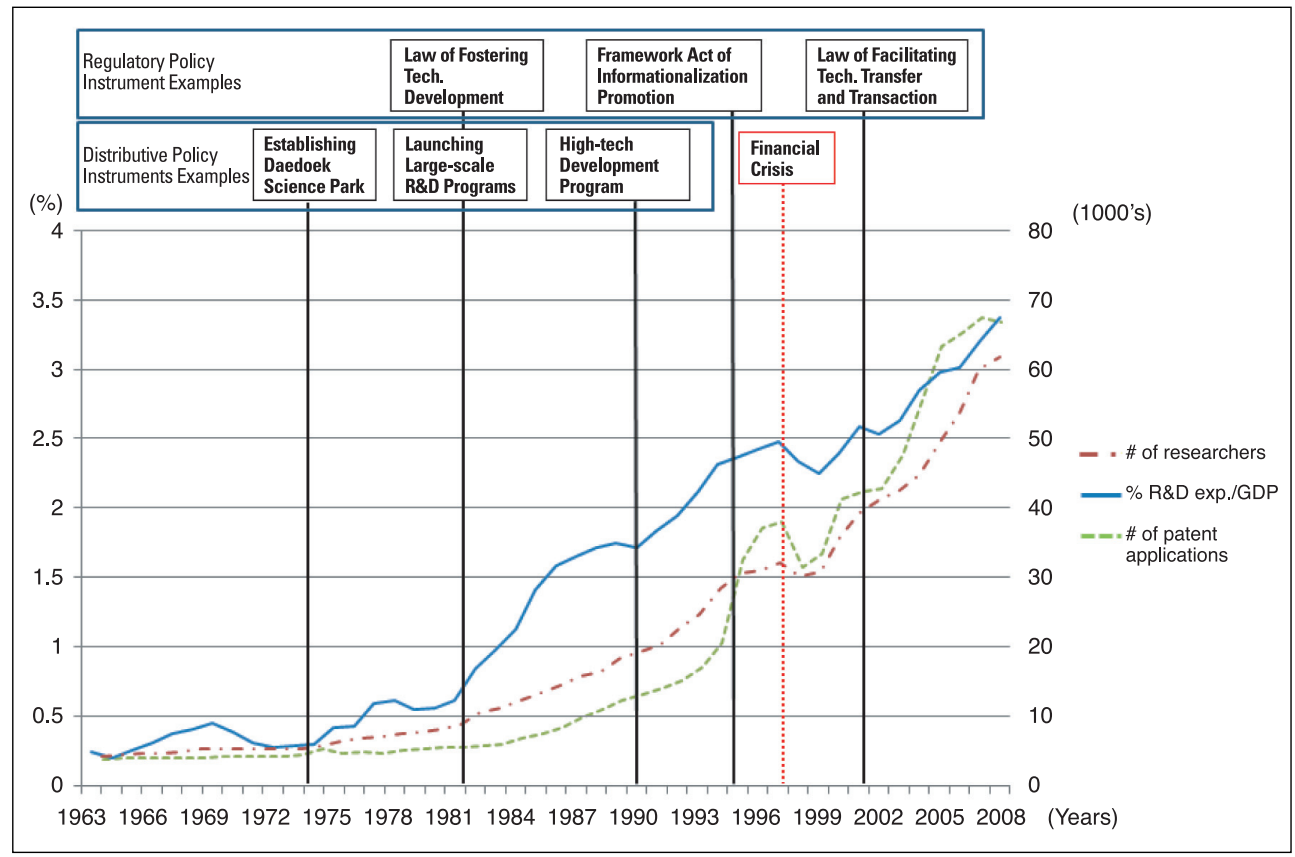




\section{R\&D Expenditure}

As noted, the '60s and '70s was a period of setting the foundation for the development of S\&T. Even though the net amount of the R\&D expenditure was insignificant and the absolute amount still remained lower than that of advanced countries, the rate of R\&D investment grew steadily during this time.

R\&D expenditure as a percentage GDP has increased since the Korean government actively implemented S\&T policy. R\&D investment comprised $0.58 \%$ of the GDP in 1980, and it increased to $1.56 \%$ in 1985 . This rapid increase owes partly to the Chun Doo-hwan administration's S\&T policy of creating large-scale R\&D programs targeting specific technology fields by benchmarking advanced countries.

From 1993 to 1997, President Kim Young-sam focused a lot of his attention on S\&T development, and he increased the budget for S\&T development and R\&D significantly (16.6\% annually), a large part of which was invested in the ICT fields.

R\&D performance in the 2000s reflects the policies implemented to build a national innovation system. First, the government continued to increase investment in R\&D, the total investment amount reaching $\$ 34$ trillion ( $\$ 31$ billion USD) in 2008. The net budget amount increased by $10 \%$ every year (Ministry of Education, Science, and Technology, 2013). As can be seen in figure 1, national R\&D expenditure as a percentage of GDP increased to $3.37 \%$ in 2008 from $2.59 \%$ in 2001. The amount of national R\&D expenditure now surpasses that of Japan, Germany, and even the United States.

Figure 2. R\&D Investment as a Percentage of GDP

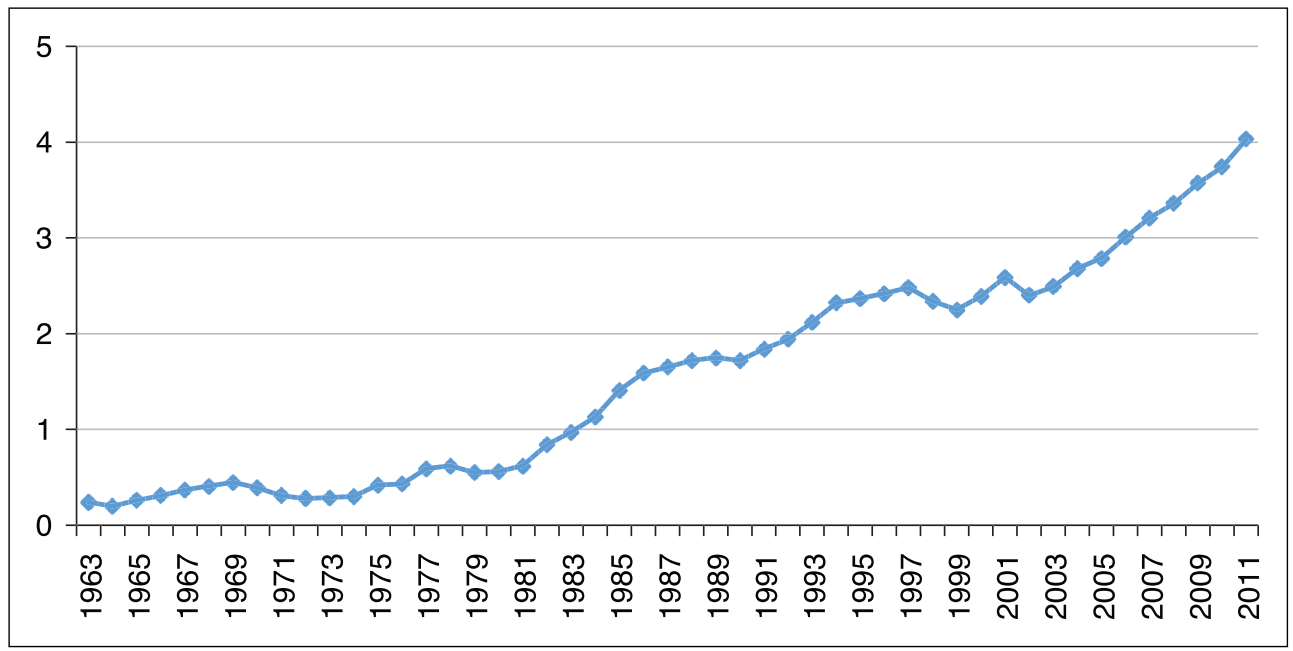




\section{Number of Researchers}

The number of researchers has been increasing steadily since 1963 except for a slight decrease before 1973 (see figure 2). In particular, a dramatic rise after 1973 was the result of a sharp increase in the number of researchers who were hired, as many specialized research institutes were established after a law supporting specific research institutes was revised, as well as of the government's invitations in the mid-1970s to overseas researchers to join projects, as more advanced $S \& T$ personnel were required to directly support heavy chemical industry development. The government also established and implemented a long-term plan for human resource demand supply and demand in 1971.

Moreover, in the early ' 80 s, the Chun doo-hwan administration enacted a law to reduce taxes and provide tax exemptions, which gave incentives to firms establishing research laboratories. As more firms established research laboratories, the demand for more researchers increased. As a result, the number of researchers grew incrementally from 10 researchers per 1,000 population in the ' 80 s to over 60 researchers per 1,000 population in 2011.

The number of researchers continued to grow in the 2000s, as the Kim Dae-jung and Roh Moo-hyun administrations increased S\&T R\&D expenditure in order to overcome the financial crisis. In 2003, $62.7 \%$ of the researchers worked in the private sector, while $30.1 \%$ of them worked in the universities and $7.3 \%$ worked in the public research institutes. The growth rate of the number of researchers in private companies

Figure 3. Number of Researchers (by 1,000 population)

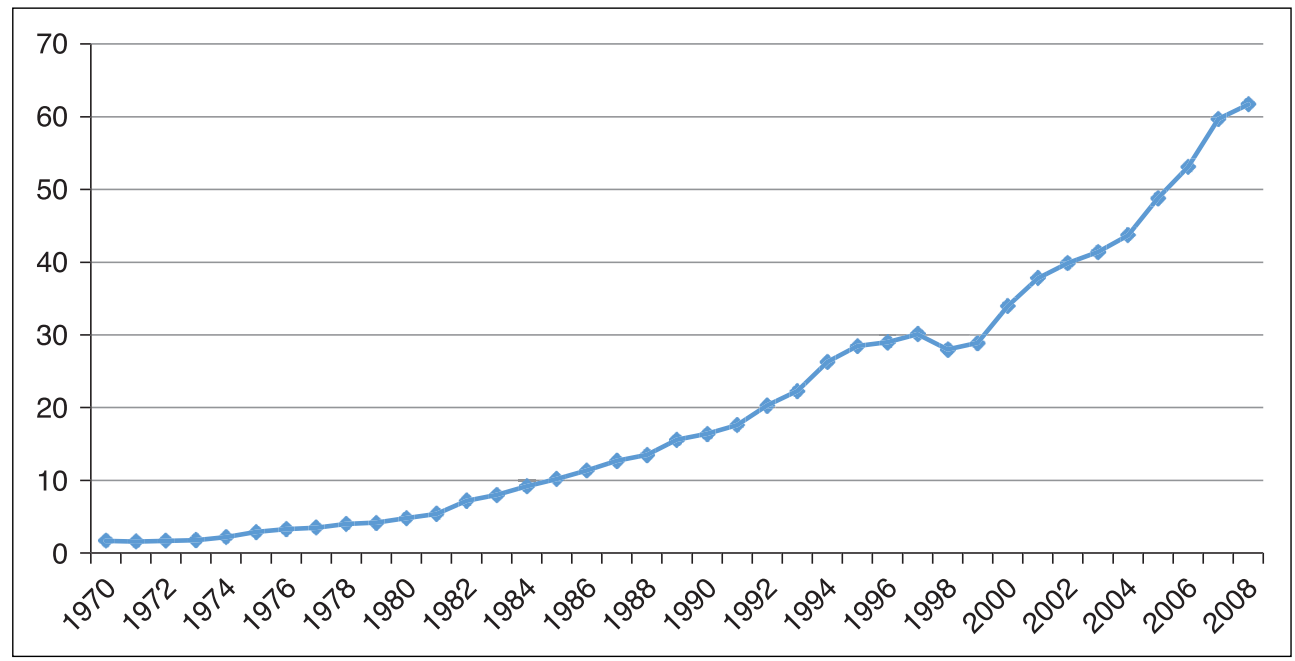


increased by $5.1 \%$ in 2013, a higher growth rate than the total growth rate of the number of researchers, which was at $4.4 \%$. On the other hand, the growth rate of the number of researchers in the public research institutes and universities remained at $2.1 \%$ and $3.7 \%$ respectively.

\section{Patents and Publications}

National R\&D performance in terms of patent applications is shown in figure 3. The Korean government made a drastic financial investment and provided policy support when developing technology together with GRIs and the private sector. In addition, the government encouraged the development of heavy industry, effecting deregulation policies to support this development. As a result, the number of patent applications steadily increased between 1963 and 1973 and sharply increased in 1974. The sharp increase in patent applications seems to have been triggered by the change in the legal system. The government revised the patent law in 1973 so as to protect foreigners' right to promote industrial development by technology transfer in order to establish a patent system that would be recognized by the international community.

The number of patent applications increased sharply again in 1994. It decreased slightly in 1997 due to the Asian economic crisis but has increased again since then.

Figure 4. Number of Patent Applications, 1963-2011

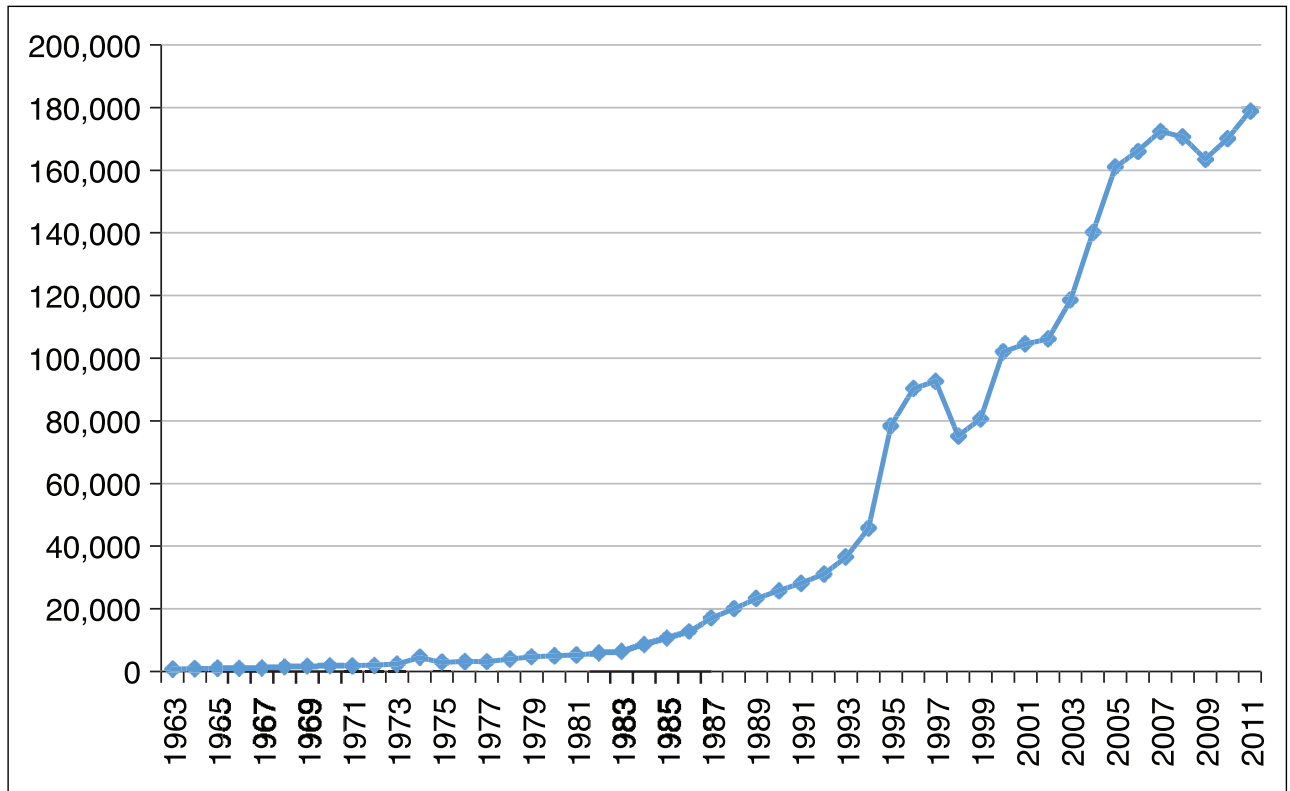


The increase in the number of patent applications owes to several factors. First, in 1994, the government implemented a specialization policy for GRIs. In 1995, the concept of a star project was introduced, and projects deserving special a priority were identified by GRIs.

The number of patent applications increased sharply yet again in 2003. The number of domestic patent registrations also increased from 104,612 patents in 2001 to 170,632 patents in 2008. It seems that the number of patent applications increased owing to the policies actively supporting patent application. The Kim Dae-jung administration enacted a law in 2001 that supported patenting of GRIs and technology transfer. The number of patent applications decreased sharply after 2008 and then bounced back again, which was to an extent due to another financial crisis.

Publication is usually treated as an outcome of R\&D performance, and the number of articles cited in the SCI gradually increased through 1990s and early 2000s, when the Korean government began monitoring citations, and increased sharply after 2006. The plan for nurturing the natural sciences and engineering human resources implemented in 2006 has no doubt contributed to the increase in the number of SCI citations. The MST made the number of SCI citations a major performance indicator of national R\&D projects. For example, the number of SCI citations served as a means of assessing the first phase of the BK 21 project, which was the largest basic R\&D program implemented in Korea. Even though it is not indicated on the graph, the number of SCI citations has been increasing steadily ( 2 times in 2000; 2.63 times in 2003; 3.22 times in 2006), and Korea's world ranking has also improved (it rank 35th in SCI citations in

Figure 5. Number of SCI Citations, 2001 to 2011

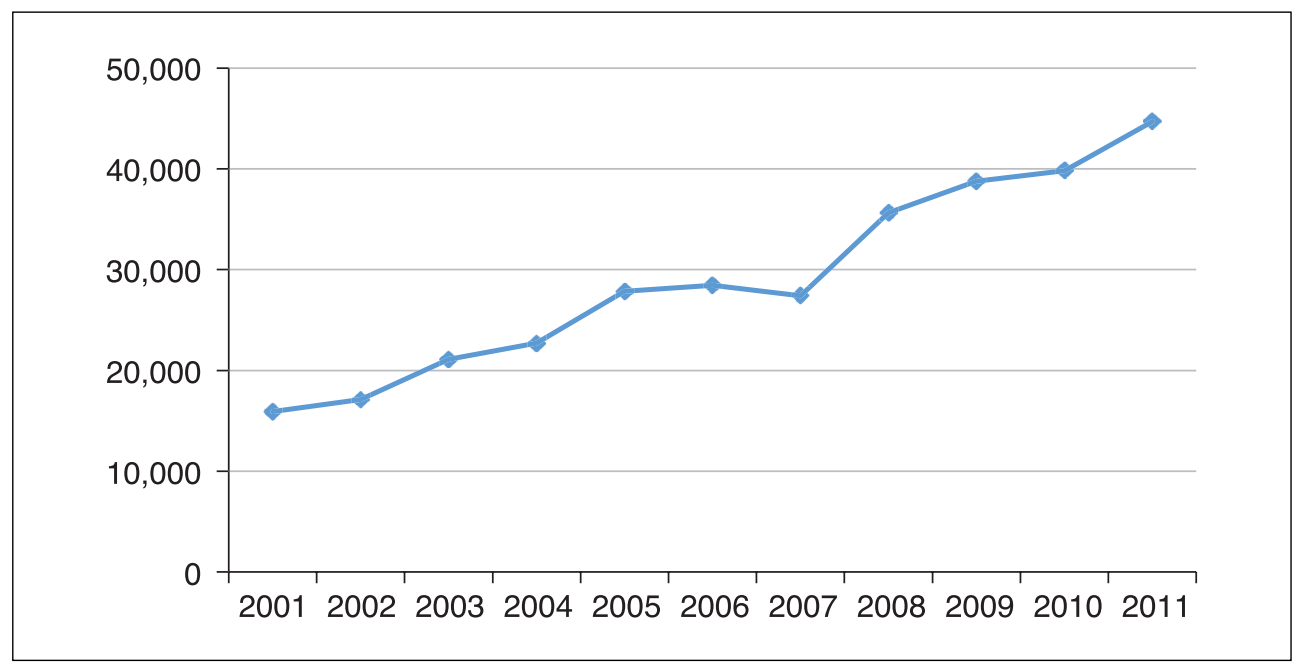


2000,30 th in 2003, and 28th in 2006).

The Korean government also started to focus not just quantity but also quality. For scientific publications, the number of citations received was adopted as a qualitative performance measurement. In a comparison of the citation frequency of papers published in international academic journals in 2010, Korea ranked 28th at 3.22 times, while the United States ranked 3rd at 6.46 times, the UK ranked 6th at 5.93 times, Germany ranked 8th at 5.65 times, and Japan ranked 20th at 4.38 times. With respect to the number of papers published in the three leading science journals (Nature, Science, and Cell), 29 papers were published by Korean authors in 2010, while 1,454 were published by U.S authors, 324 by UK authors, 278 by German authors, 176 by Japanese authors, and 48 by Chinese authors (MST, 2011)

\section{CONCLUSION}

The Korean government designed and implemented a variety of intensive policy tools to rapidly advance and improve the level of S\&T development capability, which eventually contributed to economic development. The government has been sought to promote $S \& T$ R\&D in the private sector using various policy methods, such as tax relief, subsidies, loans, personnel, and procurement. The government also established various technology development funds in such formats direct subsidy, technology loans, and investment. Moreover, the government made efforts to solve human resource issues by supplying better researchers and financial support, utilizing the specialized researcher system.

Korea's approach to acquiring technology has had both positive and negative effects. On the positive side, its approach has enabled it to acquire technologies at lower cost and avoided the constraints often imposed by multinationals on local firms who sought to develop their own capability. The approach was effective in maintaining independence from the dominance of multinationals. On the negative side, Korea had to give up access to new technologies that might have been available through direct links with foreign firms. By restricting foreign direct investment, Korea lost a chance to adopt global standards in domestic market (Chung, 2010). The most important lesson here is that had it not been for the well-educated workforce, it would not have been possible for Korea to succeed in acquiring and assimilating foreign technologies through technology import. 


\section{REFERENCES}

Ahn, C. Y. 1991. Technology transfer and economic development: The case of Korea. In K. Minden (ed.), Pacific cooperation in science and technology (pp. 00-00). Honolulu, HI: East-West Center.

Cho, H., \& J. Sung. 2005. The president and science and technology leadership. Paper presented at the Korea Association of Public Administration spring conference.

Chung, S. 1982. Korea's science and technology policy: One policy maker's testimony. Seoul: Chung-Woo Sa.

Chung, S. 2010. Innovation, competitiveness, and growth: Korean Experience. Paper presented at the Annual World Bank Conference on Development Economics.

Chung, S., \& L. M. Branscomb. 1996. Technology transfer and international cooperation. In L. M. Branscomb and Y. H. Choi (eds.), Korea at the Turning Point. Westport, CT: Praeger.

Freeman, C. 1987. Technology policy and economic performance: Lessons from Japan. Pinter, London

Hobday, M. 1995. Innovation in East Asia: The challenge to Japan. Aldershot, UK: Edward Elgar.

International Monetary Fund. 2012. (www.imf.org).

Jones, R., \& B. Yoo. 2010. Korea's green growth strategy: Mitigating climate change and developing new growth engines. OECD Economics Department Working Papers no. 798.

Kim, G. 2008. Anatomy of Nation's Science and Technology - Landscape of Science and Technology in the 1960s. Yeok Sa Bee Pyong, 85: 236-261.

Kim, L. 1997. Imitation to innovation: The dynamics of Korea's technological learning. Cambridge, MA: Harvard Business School Press.

Kim, L., \& C. Dahlman. 1992. Technology policy for industrialization: An integrative framework and Korea's experience. Research Policy, 21(5): 437-452.

Kim, Y., B. Lee, and Y. Lim. 1999. A comparative study on managerial features between public and private R\&D organizations in Korea: Managerial and policy implications for public R\&D organizations. International Journal of Technology Management, 17(3).

Kim, Y.-H, \& J. W. Yoon. 2008. The congruence of the Korean science and technology administration system. Korean Journal of Public Administration, 46(4): 175-199.

KISTEP. 2009. Guideline for R\&D Pre-feasibility Studies, KISTEP. Seoul; Korea

Koo, B.-Y. 1986. Role of government in Korea's industrial development. In K. Lee (ed.), Industrial development policies and issues (pp. 00-00). Seoul: KDI.

Korean Industrial Technology Association. 1994. Industrial technology white paper, 
Seoul: KITA Press.

Lee, Y. J. 2011. Paper presented at the plenary session of the international symposium on global centers of excellence, Ajou University, South Korea, August 18-20.

Lowi, T. J. 1968. Four systems of policy, politics, and choice. Public Administration Review, 33(3): 298-310.

Min, C. 2007. 20 years of science and technology policy research. Seoul: STEPI.

Ministry of Education and Human Resources Department. 2001. Brain Korea 21 project: An outcome report. Seoul, Korea

Ministry of Education, Science, and Technology. 2013. National Science and Technology Indicators. http://www.ntis.go.kr.

Green Technology Center. 2012. Green Technology Policy-roadmap. Green Technology Center: Seoul, Korea.

Ministry of Science and Technology [MST]. 2007. Report on the survey of R\&D in science and technology. Seoul: MST.

Moon, M. and K.S. Kim. 2001. A Case of Korean Higher Education Reform: The Brain Korea 21 Project. Asian Pacific Education Review, 2(2): 96-105.

MST. 2008. 40-year history of science and technology. Seoul: MST.

Oh, W. 2006. How did Park Jung-hee make a strong economy? Seoul: Dong Seo Mun Hwa Sa.

Oh, D.S. 2002. Technology-based Regional Development Policy: Case study Daedeok Science Town, Daejeon Metropolitan City, Korea. Habitat International, 26: 213-228

Oh, D.S. \& I. Masser. 1995. High-Tech Centers and Regional Innovation - Some Case Studies in the U.K, Germany, Japan and Korea. In Bertuglia, C.S. (eds.) Technological Change, Economic Development and Space. Berlin; New York: Springer

Oh, D.S., \& I. Yeom. 2012. Daedeok Innopolis in Korea: From science park to innovation cluster. World Technopolis Review, 1(2): 141-154.

Park, G. 2006. Background and meaning of government organization reform for science and technology innovation. Paper presented at the Korea Technology Innovation Society fall conference.

Furman, J.L., M. E. Porter, S. Stern. 2002. The determinants of national innovative capacity. Research Policy, 31: 899-933.

Spence, M., \& D. Leipziger. 2010. Globalization and growth implications for a post-crisis world. International Bank for Reconstruction and Development. https://openknowledge.worldbank.org/handle/10986/2440.

Science and Technology Policy Institute [STEPI]. 2007. Korea innovation survey: Manufacturing sectors. Seoul: STEPI.

Vernon, R. 1977. Storm over multinationals. Cambridge, MA: Harvard University 
Press.

Yim, D. S. 2004. Korea's national innovation system and science and technology policy. Seoul: STEPI.

U.S. Energy Information Administration. 2011. Environmental impact assessment, South Korea, country analysis brief.

United Nations. 2011. Human development report. http://hdr.undp.org/en/content/ human-development-report-2011. 